\title{
Omeprazole: Inhibiting the final common pathway to acid secretion - The acid pump
}

\author{
A.B.R. THOMSON, MD, PHD, FRCPC, FACP
}

\begin{abstract}
Omeprazole is the first agent in a new therapeutic advance class the proton or acid pump inhibitors - which represents a significant therapeutic advance in the treatment of acid related diseases. Omeprazole reduces gastric acid secretion at its source - the acid pump of the parietal cell, thereby offering precise and consistent clinical effects. Omeprazole once daily has been shown to heal over $80 \%$ of duodenal ulcers within two weeks and over $95 \%$ within four weeks. In gastric ulcer, the healing rates are up to $80 \%$ within four weeks and $96 \%$ within eight weeks. More patients are free from symptoms earlier on omeprazole therapy than with the $\mathrm{H}_{2}$ receptor antagonists. Omeprazole is also effective in healing and symptom relief even where prolonged $\mathrm{H}_{2}$ receptor antagonist therapy has been unsuccessful. Omeprazole has been shown in clinical trials to be the first consistently effective treatment of erosive/ulcerative reflux esophagitis. Complete healing is achieved in the majority of patients and symptom relief is rapid. In clinical trials with $20 \mathrm{mg}$ once daily, over $70 \%$ of patients healed within four weeks and up to $85 \%$ healed within eight weeks. Also, patients with erosive/ulcerative reflux esophagitis resistant to three months or more of treatment with full therapeutic doses of $\mathrm{H}_{2}$ receptor antagonists have shown significant benefit, with healing rates of $49 \%$ within four weeks and $73 \%$ within eight weeks of therapy with omeprazole. The rare Zollinger-Ellison syndrome has been difficult to treat in the past due to the massive hypersecretion of gastric acid. Omeprazole has proved highly effective in this syndrome, being well tolerated by patients who have received more than five years of continuous treatment with daily oral doses up to $160 \mathrm{mg}$. In summary, in extensive clinical trials omeprazole has been shown to be highly effective in the treatment of duodenal and gastric ulcers, erosive/ulcerative reflux esophagitis and Zollinger-Ellison syndrome. Omeprazole is well tolerated and is without any established side effects when used for short periods. It remains to be established whether $\mathrm{H}_{2}$ blockers still represent the best available therapy for acute treatment of peptic disorders, and whether maintenance therapy is best achieved with $\mathrm{H}_{2}$ blockers or with proton pump blockers. Can J Gastroenterol 1989;3(2):61-71 (Pour résumé, voir page 62)
\end{abstract}

Key Words: Acid pump, Duodenal ulcers, Gastric ulcers, Omeprazole

Division of Gastroenterology, University of Alberta, Edmonton, Alberta

Correspondence and reprints: Dr A.B.R. Thomson, Division of Gastroenterology,

519 Robert Newton Research Building. University of Alberta. Edmonton, Alberta T6G 2C2

This paper is to be presented at the symposium 'Omperazole and peptic ulcer disease'

in Toronto, Ontario on May 12

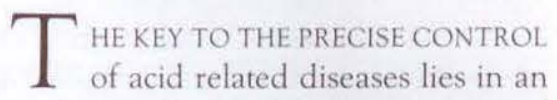
understanding of the proton pump of the parietal cell (1). Gastric acid is secreted by the proton pump of the parietal cell located in the oxyntic glands of the gastric mucosa. A large concentration gradient of hydrogen ions is established across the secretory membrane in the parietal cell and this results in a substantial difference in $\mathrm{pH}$ between the cytosol of the parietal cell ( $\mathrm{pH} 7.4)$ and the lumen of the secretory canalicula (approximately $\mathrm{pH} 1$ ). The parietal cell has an extensive system of secretory canaliculi and tubulovesicles and is specialized for acid secretion. The tubulovesicles fuse with the membranes of the secretory canaliculi to form an enlarged secretory surface when the parietal cell is stimulated

Hydrogen ions are secreted across the surface by the proton pump and are exchanged for potassium ions. This pump is an enzyme, $\mathrm{H}^{+}, \mathrm{K}^{+}$-ATPase, that exchanges hydrogen ions from the cytosol of the parietal cell with potassium ions from the secretory canaliculi. This exchange is preceded by the passive movement of hydrogen ions and chloride ions out of the cell cytoplasm into the secretory canaliculi upon stimulation of the parietal cell. The net effect is that hydrochloric acid is formed in the secretory canaliculi. Thus, this enzyme, $\mathrm{H}^{+}, \mathrm{K}^{+}$ATPase, the final common pathway for 


\section{L'omeprazole: Inhibiteur de la voie commune finale de la sécretion acide - La pompe à acide}

RESUME: L'omeprazole est le premier agent d' un nouvelle classe de substances thérapeutiques avancées - les inhibiteurs de la pompe à acide ou à proton - qui représentent un progrès important dans le traitement des affections associés à l'acide gastrique, Lomeprazole réduit la sécretion d'acide gastrique à la source la pompe à acide de la cellule pariétale gastrique à la source - la pompe à acide de la cellule pariétale, procurant ainsi des effets cliniques précis et consistants. Administré une fois par jour, l'omeprazole a fait ses preuves en guérissant $80 \%$ des ulcères duodénaux en moins de deux semaines et plus de $95 \%$, en moins de quatre semaines. Dans le cas des ulcères gastriques, les pourcentages de guérison sont de $80 \%$ en moins de quatre semaines et de $96 \%$ en moins de huit semaines. Traités à l'omeprazole, un nombre plus élevé de patients deviennent asymptomatiques plus rapidement qu'avec les antagonistes du récepteur $\mathrm{H}_{2}$. Lomeprazole savère également efficace dans la guérison et le soulagement des symptômes, même après que le traitement prolongé aux antagonistes du récepteur $\mathrm{H}_{2}$ a échoué. D'après les études cliniques, l'omeprazole est le premier traitement de l'esophagite à reflux gastroesophagien corrosif/ulcératif dont l'efficacité est consistante. La guérison totale est obtenue pour la majorité des patients et le soulagement des symptômes est rapide. Au cours d'études cliniques où $20 \mathrm{mg}$ ont été administrés une fois par jour, plus de $70 \%$ des sujets ont été guéris en quatre semaines ou moins, et le pourcentage atteint $85 \%$ en l'espace de huit semaines. Les patients atteints d'esophagite à reflux corrosif/ulcératif, jusque-là résistants à un traitement de trois mois et plus aux antagonistes du récepteur $\mathrm{H}_{2}$ administrés à pleine dose, ont eu aussi montré des résultats significatifs avec $49 \%$ de guérisons en moins de quatre semaines et $73 \%$ en huit semaines de traitement à l'omeprazole. Par le passé, I'hypersécrétion d'acide gastrique rendait le syndrome de Zollinger-Ellison difficile à soigner. L'omeprazole a prouvé sa pleine efficacité dans le traitement de ce syndrome et le médicament est bien toléré par les patients ayant suivi un traitemerit continu pendant plus de 5 ans avec une dose quotidienne orale atteignant $160 \mathrm{mg}$. En résumé, au cours d'études cliniques approfondies, l'omeprazole a démontré sa grande efficacité dans le traitement du syndrome de Zollinger-Ellison, de l'esophagite à reflux corrosif/ulcératif, et de l'ulcère gastrique et duodenal. Utilisé sur de courtes périods, l'omeprazole est bien toléré et ne semble pas produire d'effets secondaires établis. Il reste encore à déterminer si les antagonistes du récepteur $\mathrm{H}_{2}$ représentent toujours la meilleure thérapie pour le traitement des affections peptiques, et si ce sont eux ou les inhibiteurs de la pompe à proton qui conviennent le mieux à la thérapie d'entretien. acid secretion, is known as the proton or acid pump. Evidence from monoclonal antibody studies suggests that this enzyme is specific to the parietal cell (2).

The phases of acid production include cephalic, gastric, intestinal and interdigestive stages. The cephalic phase is activated by way of the vagal nerve; the gastric phase is stimulated by peptides, amino acids and gastrin; the intestinal phase is influenced by absorbed amino acids; and the interdigestive phase is influenced by vagal nerves, mast cells and histamine. The parietal cell is stimulated to secrete acid by activation of receptors on its basolateral membrane (3). Following activation of the histamine, gastrin or acetylcholine receptors, intracellular second messengers (such as cyclic
AMP and calcium) transmit the stimulus to the secretory membrane of the parietal cell where acid secretion begins (4). Additional activators include factors such as epidermal growth factor, somatostatin and prostaglandins. The acetylcholine receptor is calcium dependent but the gastrin receptor appears to be calcium independent.

Gastrin released in response to food stimulates gastric acid secretion by the parietal cell. When the acid concentration in the stomach is high and the intragastric $\mathrm{pH}$ is low, gastrin secretion falls and further acid secretion is prevented. Thus, the gastrin mechanism is a naturally occurring feedback system which operates in response to variations in intragastric luminal $\mathrm{pH}$.

\section{WHAT IS OMEPRAZOLE?}

The binding of omeprazole to $\mathrm{H}^{+}, \mathrm{K}^{+}$. ATPase, the proton pump, is activated in the acidic environment of the enzyme in the parietal cell. Omeprazole influences acid secretion at the final common pathway rather than at the surface receptor or at the intracellular cyclic AMP, protein kinase or calcium level. Omeprazole is a sulphoxide compound containing two ring structures, pyridine and benzimidazole (Figure 1A). This lipophilic compound of molecular weight 345.42 penetrates membranes rapidly, is a weak base (owing to the presence of the pyridine ring) and is activated in the acidic environment of the parietal cell close to the target enzyme, the proton pump. The oral formulation is supplied in hard gel. atin capsules containing enteric coated granules. The capsule dissolves in the stomach, but the enteric coating ensures that omeprazole is protected until it reaches the small intestine where it is absorbed. An intravenous formulation is available, supplied as a vial and an ampoule.

Omeprazole shows $\mathrm{H}^{+}, \mathrm{K}+$-ATPase inhibitory activity below $\mathrm{pH} 4$, with omeprazole gaining protons; this 'protonated' omeprazole is transformed into the active inhibitor of the proton pump. a sulphenamide (Figure 1B). The sulphenamide reacts with a mercapto (SH) group of the $\mathrm{H}^{+}, \mathrm{K}^{+}$-ATPase, which is accessible from the luminal side of the secretory canalicular membrane. A disulphide (-SS-) link is formed between the active inhibitor and the enzyme (5) and this inactivates the enzyme (6).

\section{ANIMAL STUDIES}

The acute toxicity of omeprazole in animals is low: the $\mathrm{LD}_{50}$ (the lethal dose in $50 \%$ of the animals tested) for acute oral administration in mice and rats cannot be obtained with precision, since the highest dosage that could be given practically $(4 \mathrm{~g} / \mathrm{kg})$ did not cause death in either species (7). The highest intravenous dose $(50 \mathrm{mg} / \mathrm{kg})$ that could be given in the rat was also nonlethal. In mice, the acute intravenous $\mathrm{LD}_{50}$ was estimated to be $82.8 \mathrm{mg} / \mathrm{kg}$, the dosage at the top of the range that could be physically given.

The gastrin response to acid inhibi- 


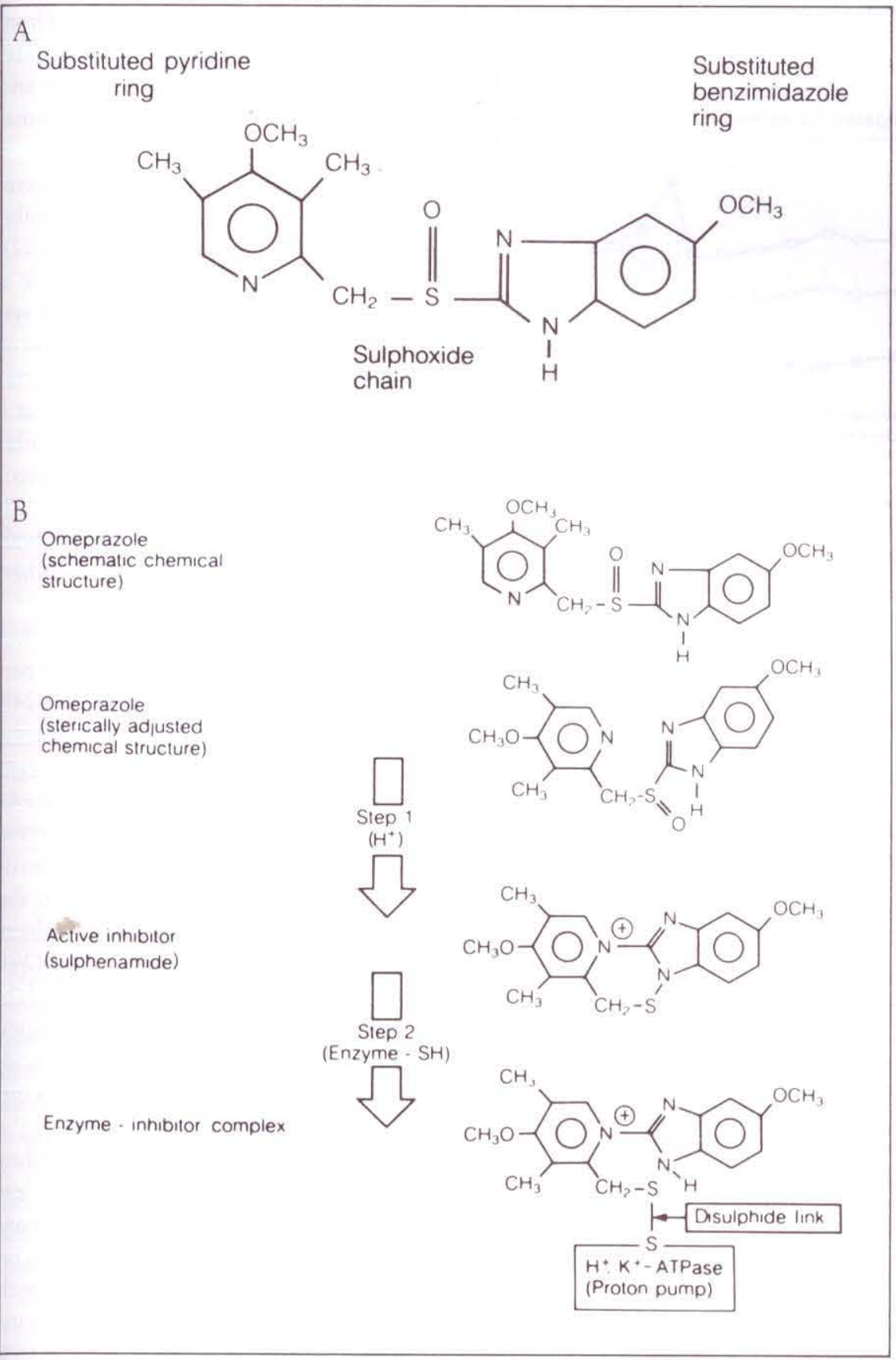

Figure 1) A Omeprazole consists of three parts, all of which are essential for its biological action, a substituted pyridine ring, a substituted benzimidazole ring and a connecting sulphoxide containing chain. B In the acidic secretory canaliculi of the parietal cell close to the proton pump, omeprazole gains protons and this 'protonated' omeprazole is rapidly transformed into a sulphenamide, the active inhibitor of the proton pump. The sulphenamide reacts rapidly with a mercapto (-SH) group of the $\mathrm{H}^{+}, \mathrm{K}^{+}$-ATPase, which is accessible from the luminal side of the secretory canalicular membrane. A disulphide (-SS-) link is formed between the active inhibitor and the enzyme and this effectively inactivates the enzyme (56)

tion is a normal physiological event: when gastric acid secretion is inhibited, the intragastric $\mathrm{pH}$ rises and there is a feedback increase in the release of gastrin from the antral G cells of the stomach. Thus, the greater the acid inhibition, the greater the rise in gastrin. In long term toxicology studies of omeprazole in the rat $(7,8)$, a dose dependent and reversible hypertrophy of the gastric mucosa was reported, including gastric enterochromaffin-like (ECL) cell hyperplasia secondary to profound and long standing acid inhibition. It is of note that in short and long term clinical use of omeprazole, no changes in mucosal histology have been reported.

In a two year toxicity study in the rat, gastric ECL cell hyperplasia and carcinoids were found (7). ECL cells are the dominant endocrine cell type in the rat gastric mucosa and gastric ECL cell carcinoids were found in some animals (8), developing towards the end of the animal's natural life span. The earliest occurrence of a carcinoid was after 19 months of continuous and profound acid inhibition for almost the entire natural lifetime of the animal. This ECL cell hyperplasia/carcinoids was found to be due to hypergastrinemia, the natural feedback response to profound acid inhibition. The proliferation was not a direct effect of omeprazole. Such proliferation is also seen following the administration of the gastrin analogue pentagastrin and also experimentally following surgical exclusion of the antrum (9). High dose ranitidine also causes hypergastrinemia and has been shown to increase gastric ECL cell density in female rats (10).

What is the relevance of these studies to man? Gastric carcinoids are rare in man $(11,12)$ and are relatively benign and slow growing $(13,14)$. Gastric ECL cell carcinoids have been associated with atrophy of the gastric body with or without pernicious anemia $(13,15,16)$ and with the Zollinger-Ellison syndrome (17). The dependence of gastric carcinoids on the trophic stimulation of gastrin is supported by the fact that gastric carcinoids have not been reported after Billroth I and II gastric resections (which involves the removal of the antral gastrin containing G cells), and that partial gastrectomy with antrectomy in patients with nonantral atrophic gastritis has resulted in regression of gastric carcinoids $(18,19)$.

\section{HUMAN PHARMACOLOGY}

The pharmacological effects of omeprazole have been extensively studied in healthy subjects and in duodenal ulcer patients in remission. Acid inhibition with omeprazole $20 \mathrm{mg}$ once daily, inhibits acid secretion over $24 \mathrm{~h}$. This effect is rapid in onset, dose dependent and increases during the first few days of treatment after which time it stabilizes. Acid control is maintained in chronic use and 


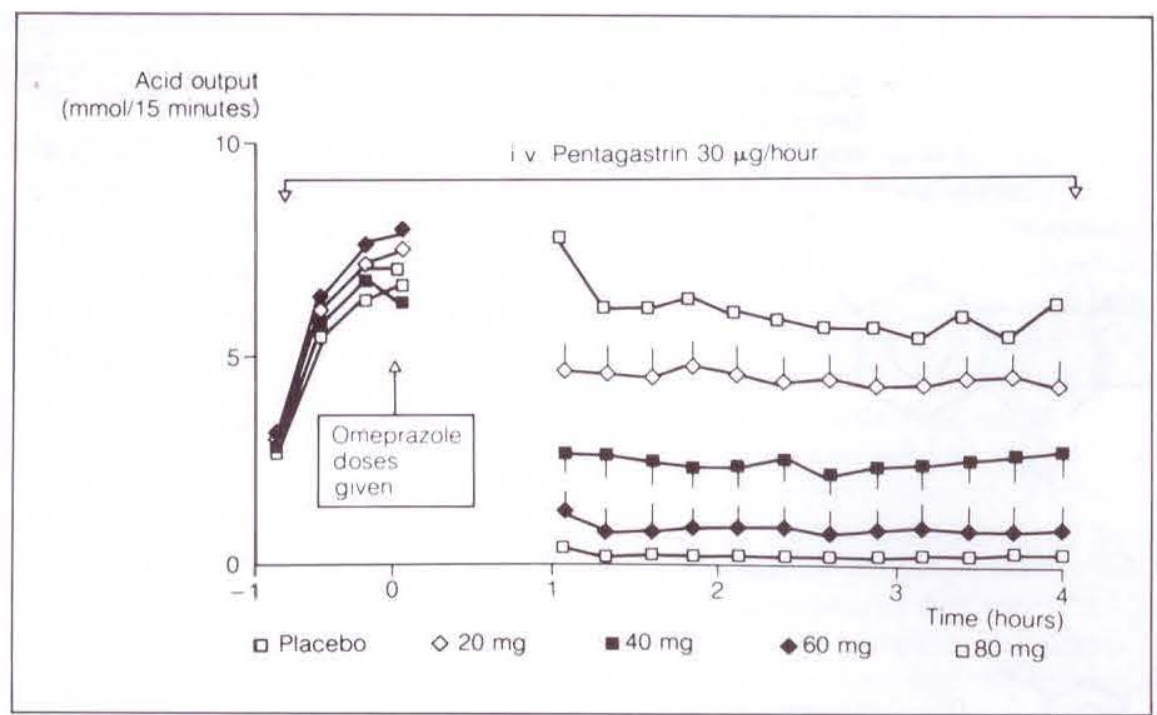

Figure 2) Stimulated acid secretion was achieved in six healthy volunteers by the administration of intravenous pentagastrin, and oral omeprazole was given in doses of 20 to $80 \mathrm{mg}$ (20). Omeprazole showed a dose dependent inhibition of acid secretion: A single $20 \mathrm{mg}$ dose reduced mean stimulated acid output by $36 \% 1$ to 4 h after administration

\section{Acid output \\ (mmol/15 minutes)}

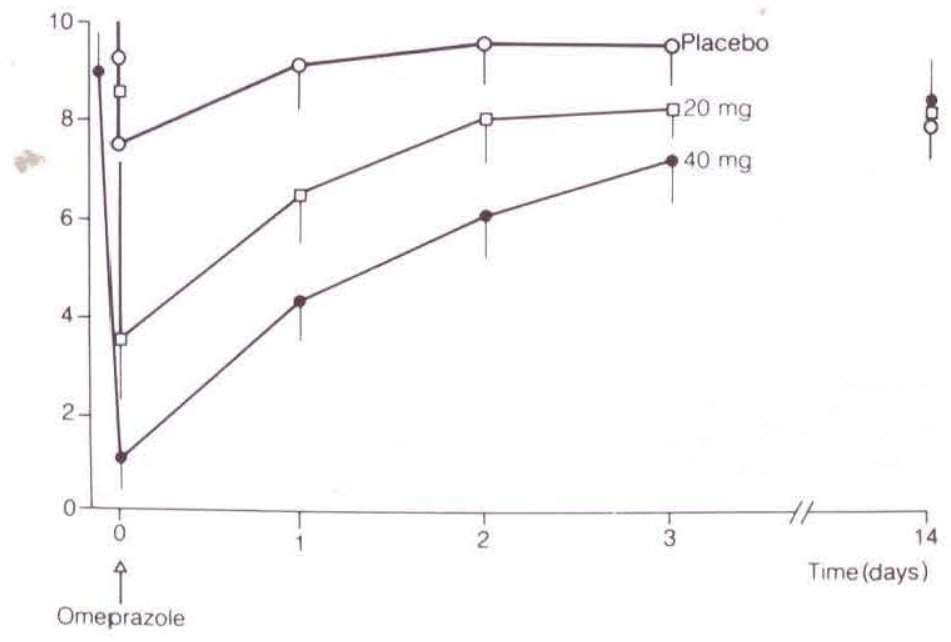

Figure 3) The omeprazole induced inhibition of acid secretion is reversible, and after a single dose of omeprazole, acid inhibition returns to normal in two to three days (20)

acid secretion smoothly returns to normal within three to four days of stopping omeprazole treatment. Omeprazole causes a dose dependent inhibition of pentagastrin stimulated acid secretion in healthy subjects (Figure 2). There is a rapid increase and then decline in the plasma concentration of omeprazole (half-life 40 mins) after a single oral 20 or $40 \mathrm{mg}$ dose (20). The peak plasma concentration of omeprazole is reached after 1 to $3 \mathrm{~h}$ when it is given as the enteric coated formulation.
The degree of acid inhibition is correlated to the area under the plasma omeprazole concentration-time curve and the given dose of omeprazole. However, the degree of acid inhibition at any given point in time is not correlated with the plasma concentration at that point in time, since the duration of acid control is long, inhibiting acid secretion long after the plasma levels of the drug are undetectable. Thus, once daily omeprazole provides effective acid inhibition during a $24 \mathrm{~h}$ period, even though omeprazole or its metabolites have disappeared from the blood. Omeprazole induced inhibition of acid secretion is reversible and after a single dose returns to normal within two to three days (Figure 3).

With repeated dosing, the antisecretory effect of this proton pump inhibitor increases and then stabilizes (20-22). This increasing effect of omeprazole is thought to be due to an enhanced systemic availability and long duration of action (23). With repeated administration of enteric coated omeprazole at a dose of $20 \mathrm{mg}$ once daily, the mean inhibition of peak acid output is approximately $60 \%$ in healthy volunteers $(22$, $24,26)$ and about $70 \%$ in patients with duodenal ulcer disease $(27,28)$ when measured $24 \mathrm{~h}$ after dosing.

Another method to assess the effect of a drug on intragastric acidity is to perform repeated measurements over a $24 \mathrm{~h}$ period. After repeated dosing with varying doses of omeprazole, acid secretion is inhibited dose dependently (Figure 4), with $20 \mathrm{mg}$ giving an average decrease in $24 \mathrm{~h}$ intragastric acidity of approximately $80 \%$. Omeprazole taken in the morning or in the early evening produces similar control of acid secretion (29). Duodenal ulcer healing with acid inhib. itors is best correlated with the degree of suppression of $24 \mathrm{~h}$ intragastric acidity (rather than suppression of nocturnal acidity) (30).

It is important to know that the reduction in $24 \mathrm{~h}$ intragastric acidity is less using standard doses of $\mathrm{H}_{2}$ receptor antagonists (31-33). For example, mean reduction in $24 \mathrm{~h}$ intragastric acidity with cimetidine $200 \mathrm{mg}$ bid has been reported to be $55 \%$, ranitidine $150 \mathrm{mg}$ bid is $69 \%$ and famotidine $40 \mathrm{mg}$ nocte is $70 \%$.

Fasting plasma gastrin concentrations remains normal until there is greater than an $80 \%$ inhibition of stimulated acid output after omeprazole. There was little or no change $24 \mathrm{~h}$ after a single dose (34). The disease induced hypergastrinemia in patients with Zollinger-Ellison syndrome has not been altered by up to 120 $\mathrm{mg}$ of omeprazole during five years of therapy $(35,36)$. In patients with ranitidine resistant peptic ulcer and reflux esophagitis who received omeprazole at a dose of $40 \mathrm{mg}$ daily, the basal plasma gastrin concentration increased a further 


\section{$\mathrm{H}^{+}$activity} $(\mathrm{mmol} / \mathrm{l})$

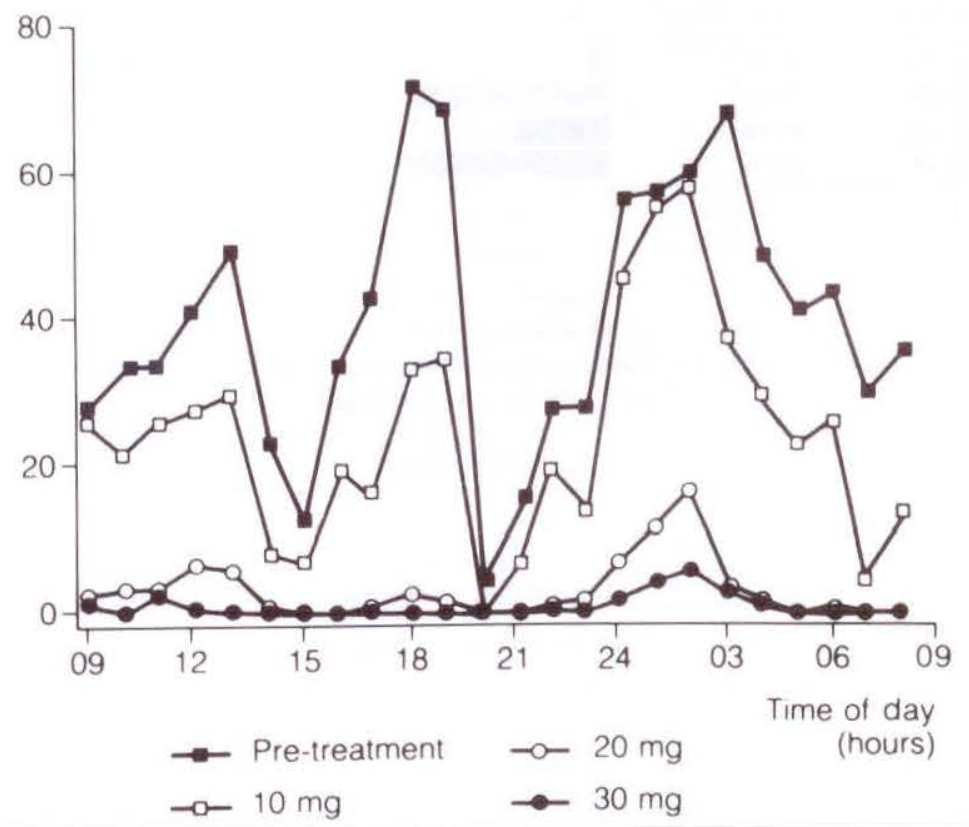

Figure 4) Twenty-four hour intragastric acidity is reduced in duodenal ulcer patients in remission after dosing with omeprazole for seven days (53). After seven days of omeprazole there is an $80 \%$ reduction of $24 \mathrm{~h}$ intragastric acidity. The same control is achieved whether omeprazole is given in the morning or in the early evening (29)

$89 \mathrm{pg} / \mathrm{mL}$ and then remained unchanged for periods of up to four years (37). Repeat endoscopic biopsies in these patients have demonstrated no treatment related histological abnormalities. The small reduction in pentagastrin stimulated pepsin output observed with high doses of omeprazole $(20,38)$ is likely due to the reduced volume of secretion from the oxyntic glands. Intrinsic factor secretion is unchanged after single or repeated dosing with omeprazole (39).

Omeprazole has no effect on plasma concentrations of somatostatin, insulin or glucagon and the slight decline in the postprandial levels of secretin is an expected result of the reduced acid load on the duodenum following gastric acid inhibition (40.41). Omeprazole has no effect on plasma levels of C-peptide, parathyroid hormones, thyroid hormones, sex hormones such as prolactin, testosterone or estradiol, or basal levels of cortisol (20,22,41-45). Gastric emptying rate is unchanged after a single dose of omeprazole (46) and the lower esophageal sphincter pressure is unaffected (47). The increases in concentration of

\begin{tabular}{|c|c|c|c|c|c|}
\hline \multirow{2}{*}{\multicolumn{2}{|c|}{ Omeprazole }} & \multicolumn{2}{|c|}{2 weeks' therapeutic gain } & \multicolumn{2}{|c|}{4 weeks therapeutic gain } \\
\hline & $\begin{array}{l}\text { zole } \\
\text { Dose }\end{array}$ & $\begin{array}{l}\text { Ranitidine } \\
\text { better }\end{array}$ & $\begin{array}{l}\text { Omeprazole } \\
\text { better }\end{array}$ & $\begin{array}{l}\text { Ranitidine } \\
\text { better }\end{array}$ & $\begin{array}{l}\text { Omeprazole } \\
\text { better }\end{array}$ \\
\hline 61 & $20 \mathrm{mg}$ & & $\longrightarrow$ & & $\longrightarrow$ \\
\hline 63 & $20 \mathrm{mg}$ & & 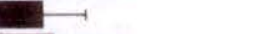 & & $\longrightarrow$ \\
\hline 69 & $30 \mathrm{mg}$ & & 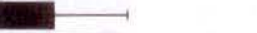 & & 1 \\
\hline \multirow[t]{2}{*}{61} & $40 \mathrm{mg}$ & & $\longrightarrow$ & & $\longrightarrow$ \\
\hline & & & $\begin{array}{rrrrrr}10 & 20 & 30 & 40 & 50 & 60 \\
& & & & & \\
& & \end{array}$ & 10 & $\begin{array}{rrr}10 & 20 \quad 30 & 40 \\
& \text { Gain }(\%)\end{array}$ \\
\hline
\end{tabular}

Figure 5) In all comparative studies of omeprazole and ranitidine in duodenal ulcer healing $(61,68,69)$, there was a 'therapeutic gain' of omeprazole at two and four weeks. The therapeutic gain represents the percentage difference (absolute) in healing rate between omeprazole and ranitidine with $95 \%$ confidence intervals

viable bacteria, nitrite and $\mathrm{N}$-nitroso compounds observed in 10 subjects given omeprazole, $30 \mathrm{mg}$ daily for two weeks (48) are not thought to be of clinical significance (49). Thus, gastric carcinoma certainly will not develop with short term use of omeprazole, but viable bacteria, nitrite and $\mathrm{N}$-nitroso compounds are seen after omeprazole therapy, and if this is prolonged for several years, the possibility of development of gastric cancer is enhanced.

Absorption of omeprazole from enteric coated formulation in a gelatin capsule occurs in the small intestine usually within 3 to $6 \mathrm{~h}$. Peak plasma concentrations are reached within 1 to $3 \mathrm{~h}$ of a single dose and absorption of omeprazole is unaffected by intake of food or antacids. The small volume of distribution of omeprazole (0.3 to $0.4 \mathrm{~L} / \mathrm{kg})(50)$ corresponds to the volume of the extracellular fluid. Omeprazole is $95 \%$ bound to plasma protein and is extensively metabolized on first pass through the liver. The systemic bioavailability of a single dose of omeprazole ( $20 \mathrm{mg}$ enteric coated) is $35 \%$ compared with the same dose administered intravenously. This bioavailability increases to approximately $60 \%$ after repeated, once daily administration (50-52).

The bioavailability of omeprazole in duodenal ulcer patients is similar to that in young, healthy volunteers (53-55). This may increase to $79 \%$ of a single oral $20 \mathrm{mg}$ dose when given in buffered solution to elderly individuals (56), possibly as a result of the age related decrease in first pass metabolism of omeprazole. Bioavailability may increase slightly to $70 \%$ in patients with impaired renal function (57). In patients with chronic cirrhosis of the liver, omeprazole has a bioavailability of approximately $98 \%$ due to impaired hepatic first pass metabolism effects (58). The plasma clearance differs between individuals, possibly due to variations in liver bloodflow and the degree of first pass metabolism (50). Despite the relatively short plasma halflife of omeprazole in man (about 40 mins) (59) once daily dosing leads to acid control over a $24 \mathrm{~h}$ interval. This duration of action of omeprazole far exceeds the short plasma half-life of omeprazole, likely due to the prolonged inhibition of action of the proton pump. 


\section{CLINICAL STUDIES}

Duodenal ulcer: Over 2000 patients have participated in clinical trials examining the therapeutic benefits of using omeprazole in duodenal ulcer. In dose ranging, double-blind studies evaluating the effects of omeprazole in doses from 10 to $60 \mathrm{mg}$ once daily in a total of 405 patients $(60,61)$, the $20 \mathrm{mg}$ daily dose was found to be highly effective, with a mean of $78 \%$ of ulcers healing within two weeks and mean of $97 \%$ healing within four weeks. Daily doses of 30 to $60 \mathrm{mg}$ were found to be similarly effective. A loading dose has been found to have no influence on duodenal ulcer healing with omeprazole (62).

Therapeutic gains in healing have been achieved with omeprazole in comparison with $\mathrm{H}_{2}$ receptor antagonists (Figure 5). Double-blind comparisons of omeprazole with $\mathrm{H}_{2}$ receptor antagonists in duodenal ulcer have included over 1400 patients. The comparison drugs were cimetidine in five trials and ranitidine in three trials $(61,63-69)$. Consistently higher healing rates were obtained in omeprazole treated patients than those treated with cimetidine in the comparative trials, both at two weeks and at four weeks. At two weeks the healing rate for patients who received omeprazole, 20 to $40 \mathrm{mg}$ daily, was in the range 58 to $82 \%$. The corresponding figures for those receiving standard doses of cimetidine were 44 to $49 \%$. At four weeks the figures were 84 to $100 \%$ for omeprazole and 74 to $84 \%$ for cimetidine. Omeprazole 20 to $40 \mathrm{mg}$ once daily also produced higher healing rates than ranitidine, 150 mg bid, both at two weeks and at four weeks. Omeprazole healed 71 to $83 \%$ of duodenal ulcers after two weeks and 92 to $100 \%$ of ulcers after four weeks. Ranitidine healed 53 to $60 \%$ after two weeks and 82 to $91 \%$ after four weeks. The recommended standard dose, $20 \mathrm{mg}$, of omeprazole produced significantly higher healing rates than standard dose ranitidine (61).

Large duodenal ulcers usually take longer to heal than small ones, but $52 \%$ of ulcers greater than $10 \mathrm{~mm}$ diameter are healed at two weeks with omeprazole versus $35 \%$ with $\mathrm{H}_{2}$ antagonists $(61,63$ $65,68)$. Healing rates with omeprazole in smokers are superior to healing rates

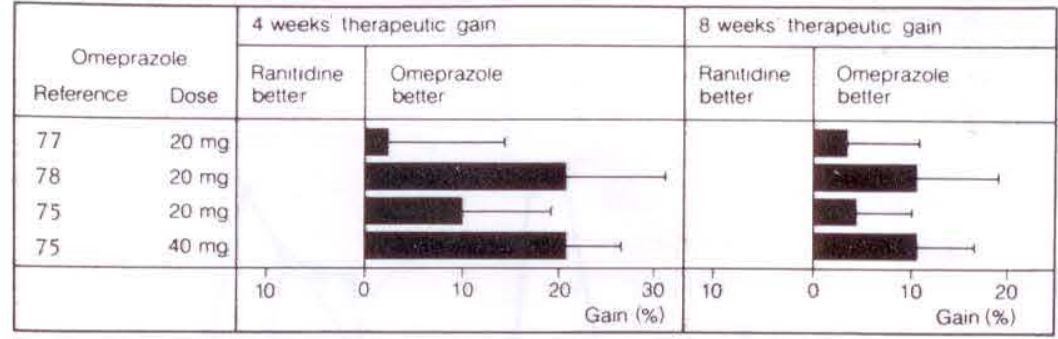

Figure 6) Omeprazole $20 \mathrm{mg}$ once daily has been compared with ranitidine $150 \mathrm{mg}$ bid in three studies $(75,77,78)$. Omeprazole healed more ulcers more quickly at weeks 4 and 8 , showing $a$ 'therapeutic gain in healing ranging from 2 to $21 \%$ at four weeks and from 3 to $11 \%$ at eight weeks. Therapeutic gain represents the absolute percentage difference in healing rate between omeprazole and ranitidine in patients with gastric ulcer, with $95 \%$ confidence limits

in patients receiving $\mathrm{H}_{2}$ receptor antagonists and the patient's age, sex and alcohol consumption has not been found to be influential on ulcer healing rates with omeprazole. The speed and degree of symptom relief with omeprazole is superior to that achieved with cimetidine and ranitidine $(61,62,70-72)$. For example, in comparison with ranitidine, omeprazole treated patients experienced fewer days of pain (median one to two days) than ranitidine treated patients (median seven days). However, both drugs provide rapid and effective relief of nocturnal pain (61).

Duodenal ulcer patients healed with omeprazole have been followed-up in periods ranging from six to 12 months $(28,60-63,73)$. In the first six months after healing, without further treatment, $34 \%$ of patients developed symptomatic ulceration. No difference in relapse rates was detected in patients originally healed after two weeks' therapy compared with those healed after four weeks' therapy (73). In a 12 month follow-up study, the incidence of ulcer relapse was $56 \%$ (60). Symptomatic ulcer recurrence in the first six months after healing with omeprazole occurred in $48 \%$ of such individuals as compared with $60 \%$ of patients healed with cimetidine (63), a difference which was not statistically significant. Sixmonth relapse rates following healing with ranitidine or omeprazole were comparable (61).

Gastric ulcer: Omeprazole has shown therapeutic gains over cimetidine and ranitidine, both in terms of healing rate and symptom relief in clinical trials involving approximately 1200 patients with gastric ulcers. Healing in gastric ulcer is generally slower than in duodenal ulcer. Four and eight week healing rates are higher with $40 \mathrm{mg}$ versus $20 \mathrm{mg} 180 \%$ versus $69 \%$ at four weeks and $96 \%$ versus $89 \%$ at eight weeks, respectively) compared to ranitidine $(59 \%$ and $85 \%$, respectively) (74). Healing rates were also higher with omeprazole than with cimetidine in prepyloric gastric ulcer (75). Studies comparing gastric ulcer healing with omeprazole $20 \mathrm{mg}$ versus ranitidine 150 $\mathrm{mg}$ bid showed that ulcers healed more quickly with omeprazole than with ranitidine, showing a therapeutic gain ranging from 2 to $21 \%$ at four weeks and 3 to $11 \%$ at eight weeks (Figure 6 ). Omeprazole healing rates at eight weeks were similar in smokers and nonsmokers and healing rates were unaffected by age, sex and alcohol consumption.

The healing rate with omeprazole 20 and $40 \mathrm{mg}$ daily, was substantially higher than with ranitidine $150 \mathrm{mg}$ bid in patients with gastric ulcer receiving NSAIDs (74). There is a statistically significant difference in favour of omeprazole in relief of daytime pain compared with ranitidine (Figure 7$)(74,76,77)$.

Six month untreated follow-up data in gastric ulcer patients has demonstrated no difference in recurrence rate following either omeprazole or ranitidine (74). Resistant ulcers: A small proportion of patients treated with $\mathrm{H}_{2}$ receptor antagonists will fail to heal their ulcers. In patients with endoscopically confirmed duodenal, gastric or anastomotic ulcer unhealed after long term therapy with $\mathrm{H}_{2}$ receptor antagonists, omeprazole was found to be very effective: duodenal ulcer patients had been treated for 


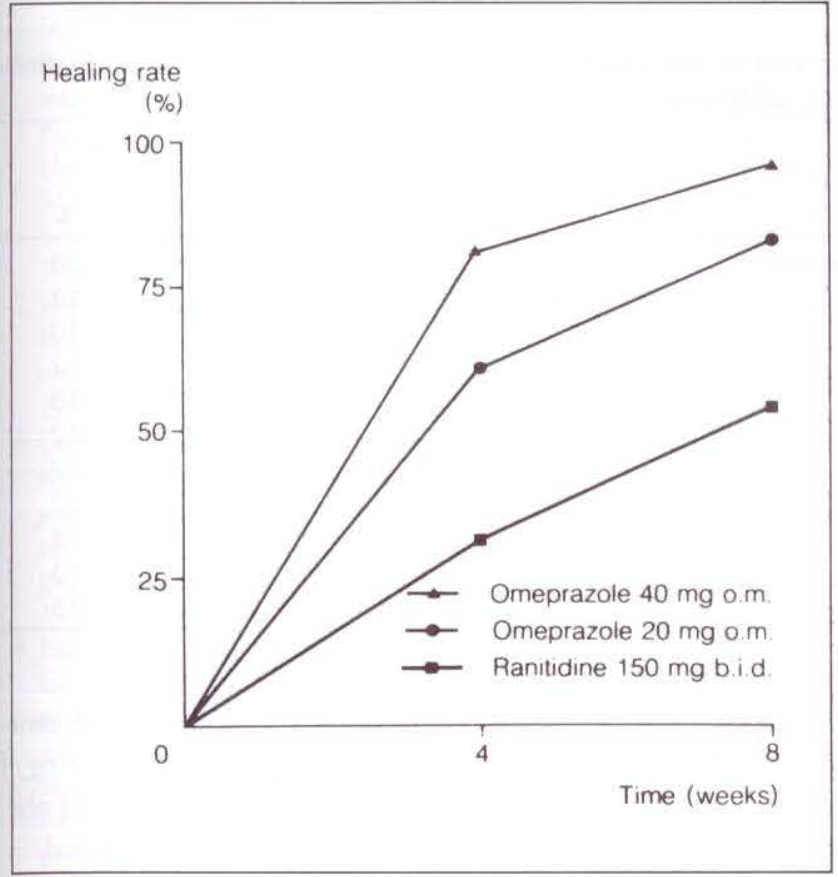

Figure 7) In a comparative trial of patients with nonsteroidal antiinflammatory drug associated gastric erosion and ulceration (75), the four week healing rates were higher for omeprazole 20 to $40 \mathrm{mg}$ once daily than for ranitidine $150 \mathrm{mg}$ bid

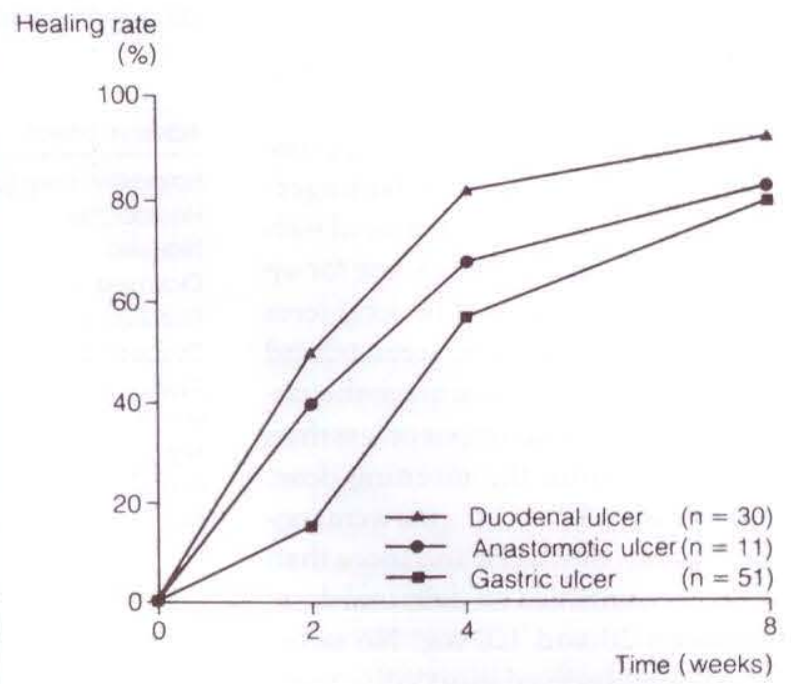

Figure 8) The effect of omeprazole on resistant ulcers was examined (79). After treating patients with cimetidine or ranitidine for a mean of 32 weeks for duodenal ulcer, 29 weeks for gastric ulcer and 46 weeks for anastomotic ulcer, oral omeprazole $40 \mathrm{mg}$ once daily was given for two to eight weeks. Over $80 \%$ of the ulcers then healed within eight weeks an average of 32 weeks with $\mathrm{H}_{2}$ receptor antagonists; those with gastric ulcer had been treated for a mean of 29 weeks; and those with anastomic ulcer had been treated for a mean of 46 weeks with either cimetidine or ranitidine. Oral omeprazole $40 \mathrm{mg}$ once daily was given for two to eight weeks and approximately $80 \%$ of the duodenal ulcers healed in four weeks as did gastric ulcers; anastomotic ulcers healed after eight weeks of omeprazole therapy (Figure 8) (78).

Reflux esophagitis: Symptomatic relief and endoscopically confirmed complete healing of reflux esophagitis has been found to be effective with omeprazole. Omeprazole has been compared with ranitidine in three double-blind studies in erosive/ulcerative reflux esophagitis (79-81). Omeprazole was given in doses of 20,40 or $60 \mathrm{mg}$ daily and ranitidine given in the standard daily dose of 150 $\mathrm{mg}$ bid. In these studies omeprazole produced significantly better healing rates than ranitidine, both at four weeks and at eight weeks, with about twice as many patients healed with omeprazole as with ranitidine (Figure 9). At four weeks the healing rates were $67 \%$ with omeprazole $20 \mathrm{mg}$ once daily versus $31 \%$ for ranitidine $150 \mathrm{mg}$ bid, whereas at eight weeks the healing rates were $85 \%$ and $50 \%$, respectively (80). Those patients still unhealed after eight weeks of ranitidine were then switched to omeprazole and 13 of these 15 patients $(87 \%)$ were healed after eight weeks of omeprazole, whereas only one of three patients unhealed after eight weeks of omeprazole therapy was healed after a further eight weeks of ranitidine therapy. The highest healing rates with omeprazole were seen in mild cases and any healing benefits of omeprazole over ranitidine were most pronounced in those patients with severe disease (80-82), with healing rates unaf- fected by age, sex, smoking or alcohol. After a four week course of treatment, a significantly larger proportion of omeprazole treated patients $(80 \%)$ were free from heartburn compared with those on ranitidine $(30 \%)$ (79-81). Overall, symptom relief was more rapid and more pronounced with omeprazole than with ranitidine ( 80 ), with $65 \%$ of omeprazole treated patients being symptom-free after two weeks, compared with $25 \%$ of ranitidine treated patients.

In patients with reflux esophagitis unhealed after at least three months of treatment with at least $1200 \mathrm{mg}$ of cime-

Figure 9) Three double-blind studies have compared omeprazole with ranitidine in erosive/ulcerative reflux esophagitis (80-82). Oral omeprazole was given at 20,40 or $60 \mathrm{mg}$ daily and ranitidine was given at $150 \mathrm{mg}$ bid. For the three doses of omeprazole, a 'therapeutic gain' in healing was observed at weeks 4 and 8 . Therapeutic gain represents the absolute percentage difference in healing rate between omeprazole and ranitidine with $95 \%$ confidence limits 
tidine daily, or at least $300 \mathrm{mg}$ of ranitidine daily, $49 \%$ were healed after four weeks of omeprazole $40 \mathrm{mg}$ daily, $73 \%$ after eight weeks and $81 \%$ after 12 weeks (83).

Zollinger-Ellison syndrome: Approximately 200 patients with ZollingerEllison syndrome have been treated with omeprazole in clinical trials, some for up to five years $(35,36,42)$. The long term mean daily dose varied between 60 and $70 \mathrm{mg}$ daily in order to achieve the target reduction in acid output of less than $10 \mathrm{mmol} / \mathrm{h}$ before the morning dose. Approximately $80 \%$ of patients were controlled within one week and more than $90 \%$ were maintained on daily oral doses of between 20 and $120 \mathrm{mg}$. No tachyphylaxis was observed in up to five years continuous treatment with omeprazole. There was a pronounced early improvement in acid related symptoms, with the therapy being well tolerated and no treatment related mucosal abnormalities found on histological evaluation of biopsy samples $(36,84)$.

\section{SAFETY}

A lack of systemic side effects of omeprazole is perhaps to be expected since the drug targets precisely the acid pump. Furthermore, it is biologically inactive at the physiological $\mathrm{pH}$ prevailing in tissues and organs other than the secretory canaliculi of the parietal cell. Nonserious, mild and transient adverse events which have been reported most often are gastrointestinal in nature and include epigastric pain, nausea, diarrhea, constipation, flatulence, headache and a few cases of skin rash. No difference in adverse events could be detected between omeprazole and placebo (85) or between omeprazole 20 to $60 \mathrm{mg}$ daily and ranitidine $300 \mathrm{mg}$ daily (Table 1). Significantly fewer gastrointestinal adverse events were reported in two comparative trials with omeprazole than with either cimetidine in prepyloric ulcer (75) or ranitidine in reflux esophagitis (80). There were no reports of gynecomastia, impotence, confusion in the elderly or increases in serum creatinine concentration with omeprazole. The pooled incidence of serious adverse events has been similar in comparative trials for omeprazole, cimetidine and ranitidine, and

TABLE 1

Most frequent adverse events reported in clinical trials of omeprazole versus ranitidine in duodenal ulcer, gastric ulcer and reflux exophagitis

\begin{tabular}{|c|c|c|c|c|}
\hline Adverse effect & Omeprazole & le & $\begin{array}{l}\text { Rani } \\
\text { Number of } \\
\text { patients }\end{array}$ & $\%$ \\
\hline Epigastric pain (aggravated) & 59 & 5.7 & 39 & 5.0 \\
\hline Headache & 33 & 3.2 & 18 & 2.3 \\
\hline Nausea & 29 & 2.8 & 24 & 3.0 \\
\hline Diarrhea & 28 & 2.7 & 13 & 1.7 \\
\hline Flatulence & 28 & 2.7 & 18 & 2.3 \\
\hline Dyspepsia & 25 & 2.4 & 33 & 4.2 \\
\hline Abdominal pain & 24 & 2.3 & 13 & 1.7 \\
\hline Vomiting & 18 & 1.7 & 18 & 2.3 \\
\hline Fatigue, asthenia & 12 & 1.2 & 14 & 1.8 \\
\hline Dizziness & 10 & 1.0 & 10 & 1,3 \\
\hline Skin rash/urticaria & 5 & 0.5 & 4 & 0.5 \\
\hline
\end{tabular}

less than the incidence of serious adverse events during placebo therapy $(4.7 \%)$, probably resulting from the untreated disease.

No histological changes in oxyntic endocrine cells of the gastric mucosa have been found after short term healing courses of omeprazole or $\mathrm{H}_{2}$ receptor antagonists in peptic ulcer disease patients $(84-86,87)$. No treatment related histological abnormalities of these cells have been found in up to five years of continuous high dose omeprazole therapy in patients with Zollinger-Ellison syndrome $(86,88)$. Once daily oral omeprazole at a dose of $40 \mathrm{mg}$ daily has been without histological sequelae over the past three years, in a trial still in progress, in peptic ulcer and reflux esophagitis patients resistant to cimetidine or ranitidine and treated with omeprazole (90). Omeprazole has not been shown to have any significant clinical effect on laboratory variables (85), and provocation testing in subjects in whom an increase in the liver enzymes aspartate and alanine aminotransferases and alkaline phosphatase have been reported, have not confirmed a further and subsequent change in those individuals $(91,92)$.

Omeprazole is metabolized by the cytochrome P-450 system in the liver. Studies have shown that omeprazole does not interfere with the pharmacokinetics of oral or intravenous theophylline or oral propranolol $(93,94)$ but interactions with diazepam $(95,96)$ and phenytoin $(95,97)$ have been described. Small changes in the low potency R-isomer of warfarin but not with the potent $\mathrm{S}$ - isomer have been described with ome prazole $20 \mathrm{mg}$ daily (98). Monitoring of omeprazole patients also receiving phenytoin or warfarin is recommended.

\section{SUMMARY}

In extensive clincial trials omeprazole has been shown to be highly effective in the treatment of duodenal and gastric ulcers, reflux esophagitis and ZollingerEllison syndrome, with fast and pronounced symptom relief both during the day and at night. Omeprazole has been well tolerated and has been without any established side effects. Time and experience will be needed to establish whether $\mathrm{H}_{2}$ blockers still represent the best available therapy for acute treatment of peptic disorders and whether maintenance therapy is best achieved with $\mathrm{H}_{\text {. }}$ blockers or with proton pump blockers.

\section{REFERENCES}

1. Omeprazole monograph Oxford: Oxford Clinical Communications. 1988:3.

2. Smolka A, Helander HF, Sachs G. Monoclonal antibodies against gastric $\mathrm{H}^{+}, \mathrm{K}^{+}$-ATPase. Am J Physiol 1983;245:G589-96

3. Berglindh T, Sachs G. Emerging strategies in ulcer therapy: Pumps and receptors. Scand J Gastroenterol 1985;20 (Suppl 108):7-14

4. Sachs G. The parietal cell as a therapeutic target. Scand J Gastroenterol 1986:21 (Suppl 118): 1-10.

5. Lindberg P, Nordberg P, Alminger $T$, Brändström A, Wallmark B. The mechanism of action of the gastric acid secretion inhibitor omeprazole. J Med Chem 1986;29:1327-9. 
6. Wallmark B, Carlsson E, Larsson H, Brändstrỏm $\mathrm{A}$, Lindberg $\mathrm{P}$. New inhibitors of gastric acid secretion: Properties and design of $\mathrm{H}^{+}, \mathrm{K}^{+}$-ATPase blockers. In: Lambert RW, ed. Third SCI-RSC Medical Chemistry Symposium. London: Whitstable Litho, 1986:293-311.

7. Ekman L, Hansson E, Havu N, Carlsson $\mathrm{E}$, Lundberg C. Toxicological studies on omeprazole. Scand I Gastroenterol 1985;20 (Suppl 108):53-69.

8. Carlsson E, Larsson H, Mattsson H. Ryberg B. Sundell G. Pharmacology and toxicology of omeprazole - with special reference to the effects on the gastric mucosa. Scand J Gastroenterol 1986;21 (Suppl 118):31-8.

9. Hakanson R, Oscarsson J, Sundler F Gastrin and the trophic control of gastric mucosa. Scand J Gastroenterol 1986;21 (Suppl 118):18-30.

10. Sundler F, Carlsson E, Hakanson R, Larsson H, Mattsson H. Inhibition of gastric acid secretion by omeprazole and ranitidine. Effects on plasma gastrin and gastric histamine, histidine decarboxylase activity and ECL cell density in normal and antrectomized rats. Scand ] Gastroenterol 1986;21 (Suppl 118):39-45

11. MacDonald RA. A study of 356 carcinoids of the gastrointestinal tract: Report of four new cases of the carcinoid syndrome. Am J Med 1956,21:867-78.

12. Goodwin JD II. Carcinoid tumors. An analysis of 2,837 cases. Cancer 1975;36:560-9.

13. Harvey RF, Bradshaw MJ, Davidson CM. Wilkinson SP. Multifocal gastric carcinoid tumours, achlorhydria, and hypergastrinaemia. Lancet 1985;1:951-4

14. Borch K. Epidemiologic, clinicopathologic, and economic aspects of gastroscopic screening of patients with pernicious anemia. Scand J Gastroenterol 1986;21:21-30.

15. Wilander E, Nordgren H, Öberg K. Nonantral gastric carcinoid tumours associated with hypergastrinaemia. Acta Med Scand 1986;219:393-7.

16. Borch K. Renvall H, Liedberg G. Gastric endocrine cell hyperplasia and carcinoid tumors in pernicious anemia.

Gastroenterology 1985;88:638-48.

17. Solcia E, Capella C, Buffa R, Frigerio B, Fiocca R. Pathology of the

Zollinger-Ellison syndrome. Prog Surg Pathol 1980:1:119-33

18. Lattes R. Grossi C. Carcinoid tumors of the stomach. Cancer 1956:9:698-711.

19. Richards AT, Hinder RA, Harrison AC. Gastric carcinoid tumours associated with hypergastrinaemia and pernicious anemia - Regression of tumours by antrectomy. A case report. S Afr Med ] 1987:72:51-3

20. Lind T, Cederberg C, Ekenved G,
Haglund U, Olbe L. Effect of omeprazole - a gastric proton pump inhibitor - on pentagastrin stimulated acid secretion in man. Gut 1983:24:270-6.

21. Cedergerg C, Ekenved G, Lind T, Olbe L. Acid inhibitory characteristics of omeprazole in man. Scand J

Gastroenterol 1985;20

(Suppl 108): 105-12

22. von Müller P, Seitz HK. Simon B, Dammann HG. Sauresekretionsverhalten und Plasmaspiegel unter einer mehrtagigen Omeprazol-gabe. Arzneimittelforsch 1983:33:1685-6.

23. Brăndström $A$, Lindberg $P$. Junggren $U$. Structure activity relationships of substituted benzimidazoles. Scand J Gastroenterol 1985:20 (Suppl 108):15-22

24. von Müller P, Seitz HK, Simon B, et al. Vierwochige omeprazol-gabe: Einfluss auf saureverhalten und basale Hormonspiegel. Z Gastroenterol 1984:22:236-40

25. Sharma B, Axelson M, Pounder RE, et al. Acid secretory capacity and plasma gastrin concentration after administration of omeprazole to normal subjects. Aliment Pharmacol Ther 1987;1:67-76.

26. Cederberg C. Lind T, Axelson M, Olbe L. Long term acid inhibitory effect of different daily doses of omeprazole 24 hours after dosing. Gastroenterology 1984;86:1043. (Abst)

27. Karvonen AL, Keyrilainen O, Uusitalo A, et al. Effects of omeprazole in duodenal ulcer patients. Scand Gastroenterol 1985;21:449-54.

28. Meyrick-Thomson J, Misiewicz JJ. Trotman IF, et al. Omeprazole in duodenal ulceration: Acid inhibition. symptom relief, endoscopic healing, and recurrence. Cooperative study. BrMed J 1984:289:525-8.

29. Pritchard PJ, Yeomans ND, Jones DB. McNeil JJ, Louid WI. Smallwood RA Effect of morning or evening dosage with $10 \mathrm{mg}$ omeprazole on $24 \mathrm{~h}$ gastric $\mathrm{pH}$ in duodenal ulcer patients in remission. Gastroenterology 1984:86:1213. (Abst)

30. Jones DB, Howden CW, Burget DW, Kerr GE, Hunt RH. Acid suppression of duodenal ulcer: A meta-analysis to define optimal dosing with antisecretory drugs. Gut 1987;28:1120-7.

31. Pounder RE, Milton-Thompson G] Williams JG, Misiewicz JJ. 24-hour control of intragastric acidity by cimetidine in duodenal ulcer patients. Lancet 1985; ii: 1069-72

32. Walt RP, Male PJ, Rawlings J, Hunt RH, Milton-Thomspon GJ, Misiewicz JJ. Comparison of the effects of ranitidine, cimetidine and placebo on the 24 hour intragastric acidity and nocturnal acid secretion in patients with duodenal ulcer. Gut 1981;22:49-54
33. Müller P, Simon B, Dammann H-G, Füerler G, Lichtwald K. Schmidt-Gayke $\mathrm{H}$. Effect of single daily doses of $\mathrm{H} 2$-blockers on acid secretion in man Schweiz Med Wochenschr 1984;114:667-71

34. Lind T, Axelson M, Olbe L.

Dose-response relationship of gastric acid inhibition in elderly patients after repeated administration of omeprazole. Dig Dis Sci 1986;31 (Suppl):352S. (Abst)

35. Lloyd-Davies KA, Rutgersson K, Sölvell L. Omeprazole in Zollinger-Ellison syndrome: Four-year international study. Gastroenterology 1986;90:1523 (Abst)

36. Maton P, McArthur K, Wank S, et al. Long-term efficacy and safety of omeprazole in patients with Zollinger-Ellison syndrome (ZES) Gastroenterology 1985;90:1537. (Abst).

37. Brunner G, Creutzfeldt W. Harke U, Lambert $\mathrm{R}$. Therapy with omeprazole in patients with peptic ulcerations resistant to extended high-dose ranitidine treatment. Digestion 1988;39:80-90.

38. Lind T, Cederberg C. Ekenved G, Olbe L. Inhibition of basal and betazole- and sham-feeding induced acid secretion by omeprazole in man. Scand J Gastroenterol 1986;21:1004-10

39. Kittang E, Aadland E, Schjonsby $\mathrm{H}$. Effect of omeprazole on the secretion of intrinsic factor, gastric acid and pepsin in man. Gut 1985:26:594-8.

40. Allen JM, Adrian TE, Webster J, Howe A, Bloom SR. Effect of a single dose of omeprazole on the gastrointestinal peptide response to food. Hepatogastroenterology 1984:31:44-6.

41. Bloom SR, Daly MJ, Cederberg C. The effect of omeprazole on meal-stimulated gastrointestinal hormones in healthy subjects. AB Hâssle: Internal Report. 1985.

42. Lamers CBHW, Jansen JBMJ. Inhibition of gastric acid secretion in Zollinger-Ellison syndrome by omeprazole, a potent and long-acting antisecretory drug. Gut 1982;23:A907. (Abst)

43. Ekenved G, Heggelund A, Lundborg P. The effect of omeprazole on circulating levels of thyroid hormones in healthy subjects. AB Hässle: Internal Report. 1983.

44. Lundborg P, Heggelund A, Johnsson G Tolerability study of $\mathrm{H168/68}$ in healthy subjects. AB Hässle: Internal Report, 1981.

45. Howden CW, Reid JL. Omeprazole, a 'gastric proton pump inhibitor': Lack of effect on renal handling of electrolytes and urinary acidification. Eur J Clin Pharmacol 1984;26:639-40

46. Horowitz M, Hetzel DJ, Buckle PJ. Chatterton BE, Shearman DJC. The 
effect of omeprazole on gastric emptying in patients with duodenal ulcer disease. Br J Clin Pharmacol 1984:18:791-4.

47. Dent J. Downton J, Buckle P, et al. Omeprazole heals peptic esophagitis by elevation of intragastric $\mathrm{pH}$. Gastroenterology 1985;88:1363. (Abst)

48. Sharma BK, Santana IA. Wood EC. et al. Intragastric bacterial activity and nitrosation before, during and after treatment with omeprazole. Br Med 1984;289:717-9

49. Colin Jones DG, Langman MJS, Lawson $\mathrm{DH}$, Vessey MP. Review: Post-marketing surveillance of the safety of cimetidine - the problems of data interpretation. Aliment Pharmacol Ther 1987;1:167-77.

50. Regardh CG, Gabrielsson M, Hoffman KJ, Löberg I, Skanberg I.

Pharmacokinetics and metabolism of omeprazole in animals and man - An overview. Scand I Gastroenterol 1985;20 (Suppl 108): 79-94.

51. Andrén K, Andersson T, Cederberg C, Skanberg I, Regardh CG. Omeprazole pharmacokinetics during repeated oral administration. Annual Pharmaceutical Congress, Stockholm 1985:112. (Abst)

52. Röhss K, Andrén K, Heggelund A, Lagerström PO, Lundborg $\mathrm{P}$. Bioavailability of omeprazole given in conjunction with food. Acta Pharmacol Toxicol 1986;59 (Suppl 5):85. (Abst)

53. Sharma BK, Walt RP, Pounder RE, Gomes MdeFA, Wood EC, Logan LH. Optimal dose of oral omeprazole for maximal 24 hour decrease of intragastric acidity. Gut 1984:25:957-64.

54. Naesdal J, Bodemar G, Walan A. Effect of omeprazole, a substituted benzimidazole, on 24-h intragastric acidity in patients with peptic ulcer disease. Scand J Gastroenterol 1984:19:916-22.

55. Lundborg P. Heggelund A, Pilbrant A Biovailability of omeprazole. Comparison between the enteric-coated formulation used in phase III clinical studies and the intended market formulation. AB Hässle: Internal Report, 1986.

56. Blanchi A, Rotenberg A, Soule JC, et al Traitement de l'ulcere duodenal en pousse par l'omeprazole. Resultats d'une étude non controlée multicentrique. Gastroenterol Clin Biol 1984;8:943-6.

57. Naesdal J, Andersson T, Bodemar G, et al. Pharmacokinetics of [14C] omeprazole in patients with impaired renal function. Clin Pharmacol Ther 1986;40:344-51.

58. Andersson T, Olsson R, Skanberg I, et al. Pharmacokinetics of omeprazole in patients with liver cirrhosis Acta Pharmacol Toxicol 1986;59 (Suppl 5):203. (Abst)

59. Lundborg P, Ekenved G, Heggelund A, Pilbrant A. Bioavailability of omeprazole from two formulations of enteric-coated granules given as a single dose. AB Hässle: Internal Report, 1983.

60. Pritchard PJ, Rubinstein D, Jones DB, et al. Double blind comparative study of omeprazole $10 \mathrm{mg}$ and $30 \mathrm{mg}$ daily for healing duodenal ulcers. $\mathrm{Br}$ Med $]$ 1985;290:601-3.

61. Bardhan KD, Bianchi Porro G, Bose K, et al. A comparison of two different doses of omeprazole versus ranitidine in treatment of duodenal ulcers. J Clin Gastroenterol 1986;8:408-13.

62. Walan A, Bergsaker-Aspöy J, Farup P, et al. Four week study of the rate of duodenal ulcer healing with omeprazole. Gut 1983:24:A972. (Abst)

63. Lauritsen K, Rune SJ, Bytzer P, et al. Effect of omeprazole and cimetidine on duodenal ulcer. A double-blind comparative study. N Engl ] Med 1985;312:958-61

64. Bader JP. Etude de l'effect de l'omeprazole sur la cicatrisation des ulceres duodenaux: comparaison avec la cimetidine. Gastroenterol Clin Biol 1986;10:191A. (Abst)

65. Archambault AP, Navert H, Pare P, et al. Omeprazole ( $20 \mathrm{mg}$ daily) versus cimetidine ( $1200 \mathrm{mg}$ daily) in duodenal ulcer healing and pain relief. Gastroenterology 1988;94:1130-4.

66. Hetzel DJ, Korman MG, Hansky J, et al. A double blind multicentre comparison of omeprazole and cimetidine in the treatment of duodenal ulcer. Aust NZ ] Med 1986;16 (Suppl 3):595. (Abst)

67. Dahlgren S, Hradsky M, Norryd C. et al. The effect of omeprazole and cimetidine on ulcer healing in treatment of duodenal ulcer patients. A Swedish multicentre study. Dig Dis Sci 1986;31 (Suppl):44S. (Abst)

68. Classen M, Dammann HG, Domschke W. et al. Kurzzeit-Therapie des Ulcus duodeni mit Omeprazol und Ranitidin Ergebnisse einer deutschen Multizengerstudie. Dtsch med Wochenschr 1985; 110:210-5.

69. Hallberg D, Backman L, Hellström M. et al. The effect of omeprazole and ranitidine on ulcer healing in treatment of duodenal ulcer patients. A Swedish multicentre study. Dig Dis Sci 1986;31 (Suppl):208S. (Abst)

70. Hüttemann W, Rohner HG, duBosque $\mathrm{G}$, et al. $20 \mathrm{mg}$ versus $30 \mathrm{mg}$ omeprazole once daily: Effect on healing rates in 115 duodenal ulcer patients. Digestion 1986;33:117-20

71. Gustavsson S, Adami HO, Löö L Nyberg A, Nyrén O. Rapid healing of duodenal ulcers with omeprazole: Double-blind dose-comparative trial. Lancet 1983; ii: 124-5.

72. Dive C. Fiasse R. Tomes S. et al Rate of duodenal ulcer healing during treatment with omeprazole. A double-blind comparison of a daily dose of $30 \mathrm{mg}$ versus $60 \mathrm{mg}$. Scand ]

Gastroenterol 1986;21 (Suppl 118):175-6

73. Halvorsen L, Andersen OK, Norgârd K. et al. Duodenal ulcer healing and relapse rate after 2 or 4 weeks treatment with omeprazole $30 \mathrm{mg}$ once daily. $\mathrm{AB}$ Hässle: Internal Report, 1986.

74. Walan A, Bader JP, Classen M, Lamers C, Piper D, Rutgersson K. Effect of omeprazole and ranitidine on ulcer healing and relapse rates in patients with benign gastric ulcer. N Engl J Med 1989:320:69-75

75. Lauritsen K, Rune SJ, Wulff HR, et al. Effect of omeprazole and cimetidine on prepyloric gastric ulcer. A double-blind comparative trial. Gut 1988;29:249-53

76. Classen M, Dammann HG, Domschke $\mathrm{W}$, et al. Abheilungsraten nach Omeprazol-und Ranitidin-Behandlung des Ulcus ventriculi. Dtsch Med Wochenschr 1985:110:628-33

77. Saggioro A, de Masi E, Curzlo M, et al Gastric ulcer healing and relief of symptoms during treatment with omeprazole $20 \mathrm{mg}$ once daily, or ranitidine $150 \mathrm{mg}$ twice daily for $4-8$ weeks - A double-blind multicentre study. Gut 1987;28:A1341. (Abst)

78. Carlsson R, Walan A, Müller-Wolf D. et al. Omeprazole, Losec ${ }^{\text {TM }}$, in the treatment of patients with peptic ulcer unhealed after treatment with $\mathrm{H}_{2}$-receptor antagonists for at least 8 weeks. AB Hässle: Internal Report, 1986

79. Klinkenberg-Knol EC, Jansen JMBJ. Festen HPM, Meuwissen SGM, Lamers CBHW. Double-blind multicentre comparison of omeprazole and ranitidine in the treatment of reflux esophagitis. Lancet 1987;i:349-51

80. Sandmark S, Carlsson R, Fausa O, Lundell L. Omeprazole or ranitidine in the treatment of reflux esophagitis. Results of a double-blind, randomized Scandinavian multicentre study. Scand Gastroenterol 1988;23:625-32.

81. Vantrappen G, Coenegrachts JL, Rutgeerts L, Schurmans P. Omeprazole $(40 \mathrm{mg})$ is superior to ranitidine in the short term treatment of ulcerative reflux esophagitis. Gastroenterology 1987:92:1681. (Abst)

82. Hetzel DJ, Dent J, Reed W, et al. Healing of peptic esophagitis with omeprazole: A dose response study. Gastroenterology 1987:92:1434. (Abst)

83. Hameeteman W, Tytgat GN. Healing of chronic Barrett ulcers with omeprazole Am J Gastroenterol 1986;81:764-6.

84. Havu N, Elm G. Analysis of gastric biopsies in patients treated up to one year with omeprazole. AB Hässle Internal Report, 1987.

85. Solvell L. Summary of tolerability and safety of omeprazole in healthy subjects and patients, $A B$ Hässle: Internal 
Report, 1986

86. Carlsson E, Solvell L. On the mechanism behind the development of gastric carcinoids in rat with special reference to man. Safety aspects. AB Hässle: Internal Report, 1986.

87. Sundler F, Simonsson M, Svensson L. Fasting plasma gastrin levels and histology of gastric biopsies from peptic ulcer patients before and after treatment with omeprazole or $\mathrm{H}_{2}$-receptor antagonists. AB Hässle: Internal Report, 1986.

88. Helander HF. Oxyntic mucosa histology in omeprazole-treated patients suffering from duodenal ulcer or Zollinger-Ellison syndrome. Digestion 1986;35 (Suppl 1): 123-9.

89. Lambert R, Creutzfeldt W, Stockmann F, Jacubaschke U, Maas S, Brunner G. Long-term omeprazole treatment in man: Effects on gastric endocrine cell populations. Digestion 1988;39:126-35.

90. Löö L. Adami HO, Gustavsson S, Nyberg A, Nyren O, Lundborg P.

Omeprazole: No evidence for frequent hepatic reactions. Lancet $1984 ; \mathrm{i}: 1347-8$. (Letter)

91. Loof L, Adami HO, Gustavsson S, Nyberg A, Nyren O. Re-exposure to omeprazole in two subjects having exhibited increased serum transaminase levels during previous treatment with omeprazole. AB Hässle: Internal Report, 1984.

92. Henry D, Brent P, Whyte 1, Mihaly G, Devenish-Meares S. Propranolol steady-state pharmacokinetics are unaltered by omeprazole. Eur J Clin Pharmacol 1987:33:369-73.

93. Gugler R. Effect of omeprazole on theophylline plasma levels after oral and i.v. theophylline, AB Hässle: Internal Report, 1985

94. Gugler R, Jensen JC. Omeprazole inhibits oxidative drug metabolism. Studies with diazepam and phenytoin in vivo and 7-ethoxycoumarin in vitro. Gastroenterology 1985;89:1235-41.

95. Lundborg P. Heggelund A, Johnsson G Effect of omeprazole and cimetidine on diazepam plasma levels after i.v. diazepam. AB Hâssle: Internal Report. 1987.

96. Pritchard PJ, Walt RP, Kitchingman GK. Somerville KW, Langman MJS. Oral phenytoin pharmacokinetics during omeprazole therapy. Br J Clin Pharmacol 1987;24:543-5.

97. Paulsen O, Höglund P. Boströ H, Sutfin T. Effect of omeprazole on plasma levels and anticoagulation effect of warfarin. AB Hässle: Internal Report, 1987. 


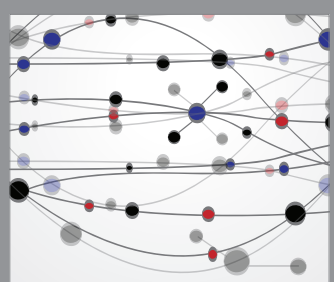

The Scientific World Journal
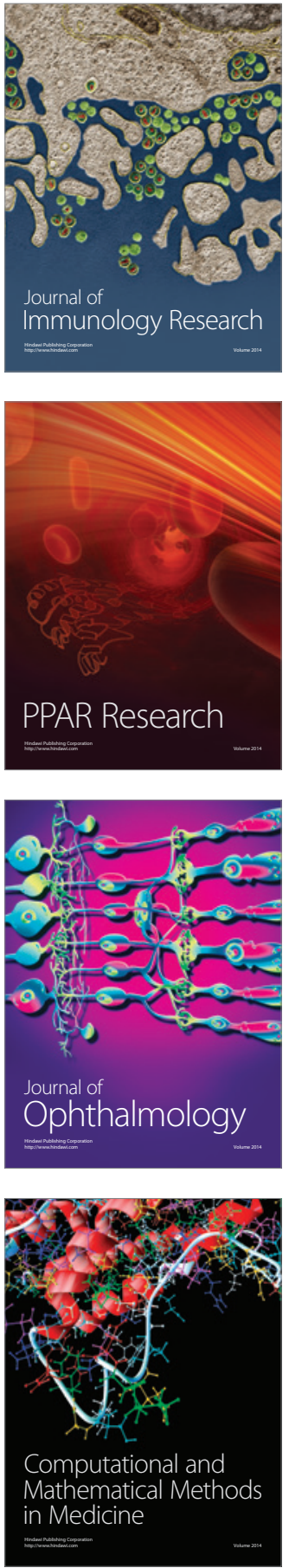

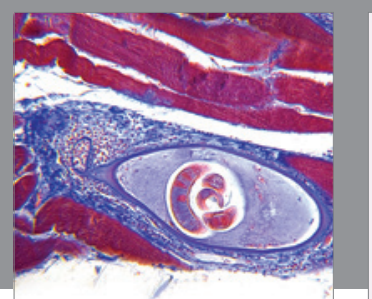

Gastroenterology Research and Practice

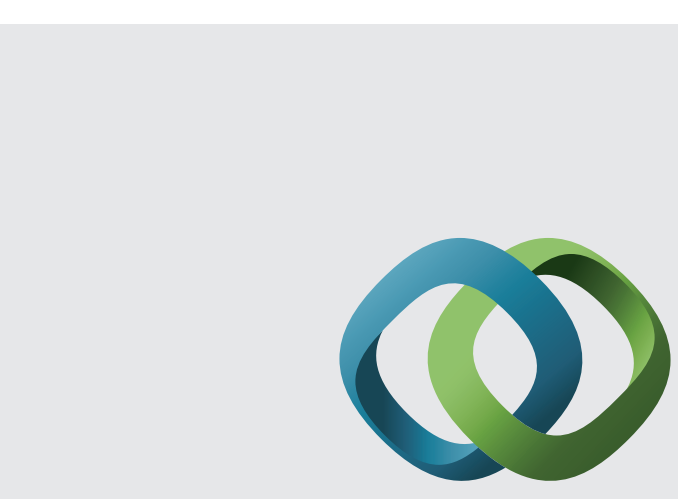

\section{Hindawi}

Submit your manuscripts at

http://www.hindawi.com
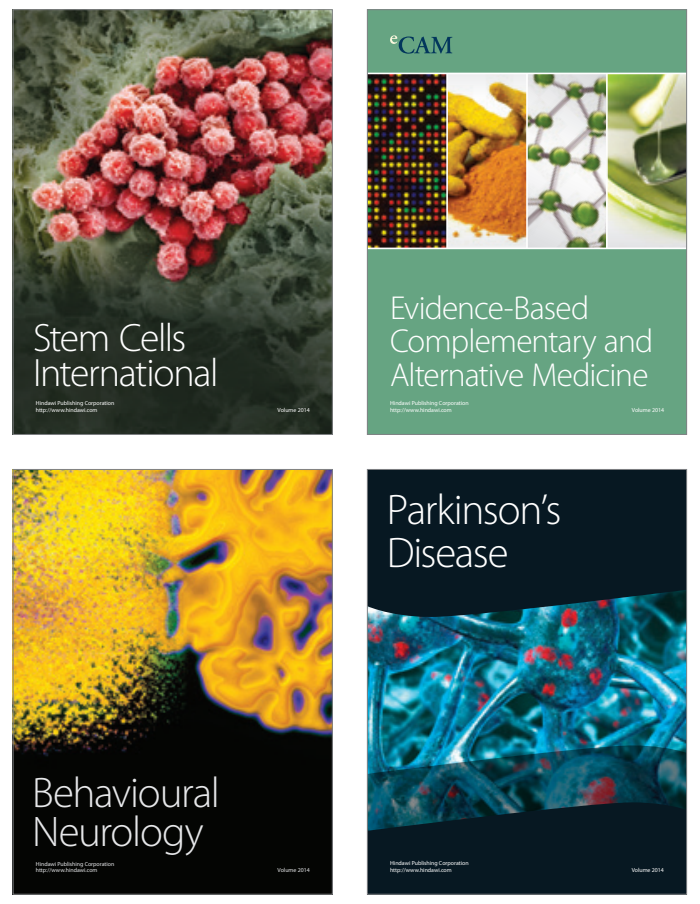
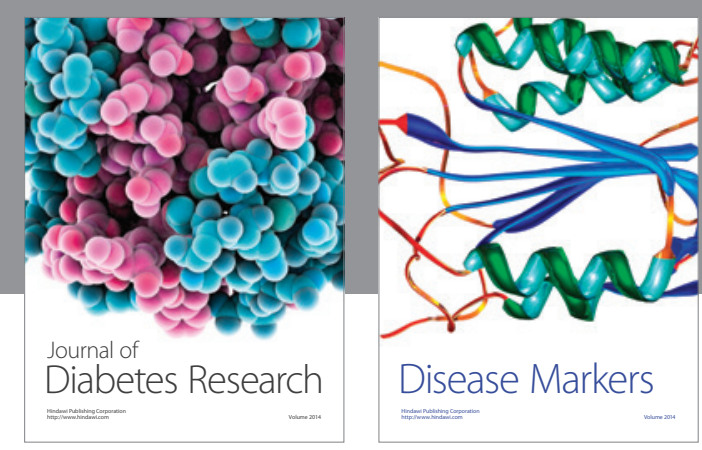

Disease Markers
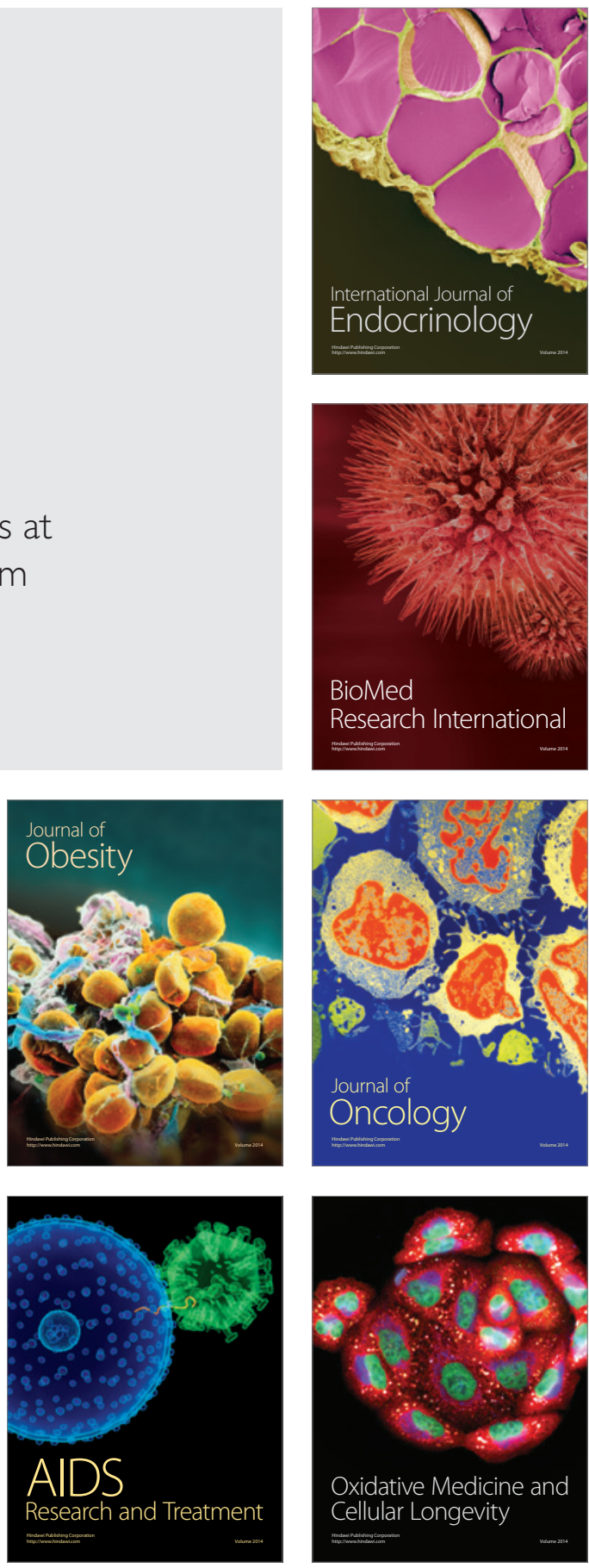